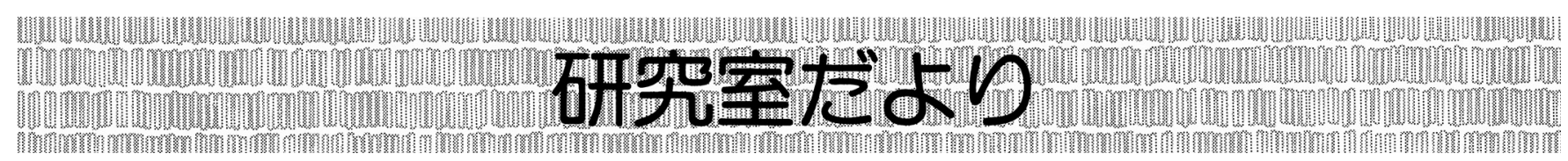

\title{
三井化学（株） 合成化学品研究所
}

山崎 舞 (三井化学 (株))

\section{1. はじめに}

三井化学は創業明治 45 年 (1912 年), 石炭化学に端を発 する総合化学メーカです。現在では, 石油化学・基礎化学 品を中心とした「基盤素材」を社会・産業の基盤として提 供しつつ，成長領域として自動車材料を中心とした「モビ リティ」, メガネレンズ材料, 歯科材料, 不織布等の「ヘル スケア」, 農薬, 包装材料等の「フード\&パッケージング」, エネルギーや農業, 医療, IoT に関わる新しいソリューショ ン事業を創出する「次世代事業」に力を入れています。

ヘルスケアの中で，オーラルケア・歯科材料事業は注力 分野の一つです。日本をはじめとするアジア，欧州，米国 といった世界各国の販売網を活かし，関係会社と足並みを 揃えた新製品開発に取り組んでいます。

国内の研究開発拠点として, 千葉県袖ケ浦市にある袖ケ 浦センターがあり，関係会社を含め約 1,000 名の研究者が 集結しています。センターには, 筆者の所属する合成化学 品研究所を含め, 5 つの研究所があり, 研究者間の交流も盛 んです。

本稿では，当社における歯科材料の研究開発について一 例をご紹介します。センサ開発がメインの部署ではありま せんが，今後の皆様とのコラボレーションに繋がれば幸い です。

\section{2. 歯科材料の研究開発事例}

当社は，ヘルスケア事業の一つであるデンタル事業の研 究開発に力を入れており, 袖ケ浦センターでは歯科材料の 研究開発が盛んに行われています。皆さんは歯科医院に定 期的に通院されているでしょうか? 虫歯（う蝕）や歯の疼 痛の治療のため通院することはあると思いますが，歯のク リーニングやメンテナンスのために通院される方はまだ少 数派かもしれません。一方で, 口腔衛生と糖尿病や動脈硬 化等の全身病は密接に関わっていると言われており，最近 では虫歯（う蝕）だけでなく歯周病の予防が大切とされて います。また，歯周病の病原菌がアルツハイマー病を引き 起こす原因となっているという論文が発表され，歯科界で は大きな驚きをもって受け止められました。

このような中，当社は虫歯治療のために使われる歯質の 修復材料や, 口腔ケア剤の開発を行っています。また，歯 科では，歯科技工士と呼ばれる専門職が，患者さんの歯列 や粘膜に合うような技工物（修復材料や入れ歯など）を作

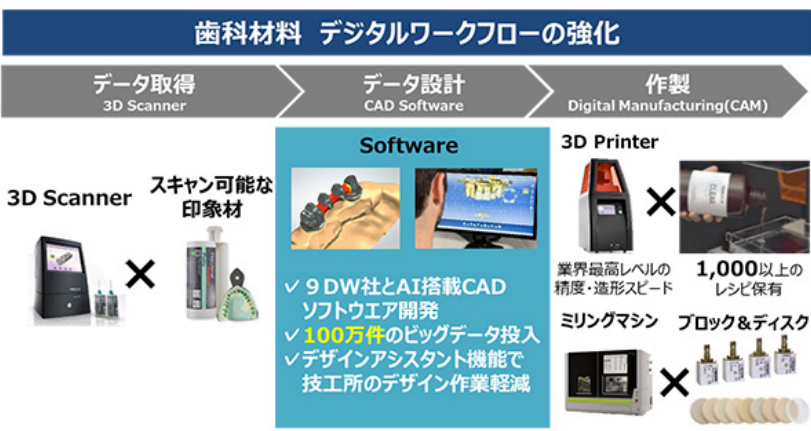

製するのが通常ですが，昨今歯科技工士が減少する一方， 高齢化社会に伴い入れ歯や修復物 (詰め物) の需要は伸び ていくと言われています。このような課題を解決するため, 口腔内の $3 \mathrm{D}$ データをスキャナで取り込んで 3D プリンタで 造形するデジタル歯科技工が今後主流になっていくと予想 されます。当社は造形精度の高い $3 \mathrm{D}$ プリンタやプリンタイ ンク開発にも力を入れており, 化学の力で歯科界に革新を もたらすべく研究を行っています

（図は当社ホームページプレスリリースより引用 https:// www.mitsuichem.com/jp/release/2018/2018_0530_01.htm)。

平均寿命が延び，高齢化社会となっている日本では，い わゆる 8020 運動（80 歳までに 20 本の歯を残すための啓発 運動）が功を奏した半面, 残存歯が多いことによる歯周病 の罹患率が高いと言われています。歯周病は感染症であり, 全身疾患との関係が次々と明らかになっている中で, 口腔 状態のモニタリングは今後一層重要になっていくと考えら れます。当社では, 唾液や呼気を対象とする非侵襲診断の 可能な口腔用センサの開発を行っています。

歯科材料のみならず，デジタルワークフローを強化しな がら, 歯科予防・治療・その後のメンテナンスに関わるモ ニタリング技術開発を進め, 口腔衛生のトータルソリュー ションを世に提供すべく，奮闘の日々が続きます。

\section{3. おわりに}

化学会社として原材料の提供だけでなく，歯科事業など 日常生活に直結する事業を有する当社について, 今回執筆 の機会を与えて下さった編修委員会の方々に感謝申し上げ ます。読者の皆様に少しでも興味を持っていただき, 歯科 分野のセンシング等について協働できるとしたら, これほ ど嬉しいことはございません。

(令和元年 7 月 12 日受付) 